\title{
Chemical cauterization of peristomal granulomas with $50 \%$ trichloroacetic acid
}

\author{
Cauterização química de granulomas periestomais com ácido tricloroacético a 50\%
}

Cauterización química de granulomas periestomales con ácido tricloroacético a 50\%

Rosaura Soares Paczek ${ }^{1 *}$, Luisa Zadra Passberg²

ORCID IDS

Paczek RS (D) https://orcid.org/0000-0002-4397-1814

Passberg LZ (D) https://orcid.org/0000-0002-8934-834X

\section{HOW TO CITE}

Paczek RS; Passberg LZ. Chemical cauterization of peristomal granulomas with 50\% trichloroacetic acid. ESTIMA, Braz. J. Enterostomal Ther., 17: e0319. https://doi.org/10.30886/estima. v17.641 IN

\begin{abstract}
Objetive: This study deals with the treatment of granulomas, one of the possible complications of the stomies, which are characterized as focal lesions, whose formation occurs due to the presence of aggressive agents to the tissues from the increase of the degree of cellularity and other tissue elements, generating annoyance and anxiety to patients. This study aims to describe the clinical results of the treatment of peristomal granulomas with the use of 50\% trichloroacetic acid (TCA). Methods: This is a case series study, carried out by professionals in a referral center for the treatment of individuals with an ostomy in the city of Porto Alegre, state of Rio Grande do Sul. Results: The study sample consisted of 13 patients who underwent follow-up for treatment of peristomal granulomas with TCA. Data collection was performed during nursing consultations, based on the observation and photographic record of the granulomas, with subsequent evolution in the individual charts. Conclusion: It was concluded from this study that the regular treatment with TCA resulted in regression of the granulomas until their total disappearance, being this acid able to be considered, therefore, a potential therapeutic option; however, it is recommended to carry out further studies on its use in stomatherapy, seeking the use of more robust clinical research methodologies and with bias control.
\end{abstract}

DESCRIPTORS: Granuloma; Cauterization; Ostomy; Stomatherapy. 


\section{RESUMO}

Objetivo: Este estudo aborda o tratamento dos granulomas, uma das possíveis complicações das estomias, os quais são caracterizados como lesões focais, cuja formação ocorre devido à presença de agentes agressores aos tecidos a partir do aumento do grau de celularidade e de outros elementos teciduais, gerando incômodo e ansiedade aos pacientes. Tal estudo tem como objetivo descrever os resultados clínicos do tratamento de granulomas periestomais com o uso de ácido tricloroacético (ATA) a 50\%. Métodos: Trata-se de estudo de série de casos, vivenciado por profissionais em um centro de referência para tratamento de indivíduos com estomia no município de Porto Alegre, estado do Rio Grande do Sul. Resultados: A amostra do estudo foi constituída de 13 pacientes que realizaram acompanhamento para tratamento de granulomas periestomais com o ATA. A coleta de dados foi realizada durante consultas de enfermagem, a partir da observação e registro fotográfico dos granulomas, com posterior evolução no prontuário individual. Conclusão: Concluiu-se, a partir deste estudo, que o tratamento regular com o ATA resultou em regressão dos granulomas até seu total desaparecimento, podendo tal ácido ser considerado, assim, potencial opção terapêutica; porém, recomenda-se a realização de mais estudos sobre sua utilização na estomaterapia, buscando a utilização de metodologias de pesquisa clínica mais robustas e com controle de vieses.

DESCRITORES: Granuloma; Cauterização; Estomia; Estomaterapia.

\section{RESUMEN}

Objetivo: Este estudio aborda el tratamiento de los granulomas, una de las posibles complicaciones de las estomias, que se caracterizan como lesiones focales, cuya formación ocurre debido a la presencia de agentes agresores a los tejidos a partir del aumento del grado de celularidad y de otros elementos teciduales, generando incomodidad y ansiedad a los pacientes. Este estudio tiene como objetivo describir los resultados clínicos del tratamiento de granulomas periestomales con el uso de ácido tricloroacético (ATA) al 50\%. Métodos: Se trata de estudio de serie de casos, vivido por profesionales en un centro de referencia para el tratamiento de individuos con estomia en el municipio de Porto Alegre, estado de Rio Grande do Sul. Resultados: La muestra del estudio fue constituida de 13 pacientes que realizaron seguimiento para tratamiento de granulomas periestomales con el ATA. La recolección de datos fue realizada durante consultas de enfermería, a partir de la observación y registro fotográfico de los granulomas, con posterior evolución en el prontuario individual. Conclusión: Se concluyó, a partir de este estudio, que el tratamiento regular con el ATA resultó en regresión de los granulomas hasta su total desaparición, pudiendo tal ácido ser considerado, así, potencial opción terapéutica; sin embargo, se recomienda realizar más estudios sobre su utilización en la estomaterapia, buscando la utilización de metodologías de investigación clínica más robustas y con control de sesgos.

DESCRIPTORES: Granuloma; cauterización; ostomía; Estomaterapia.

\section{INTRODUCTION}

Granulomas are characterized as focal lesions, whose formation occurs due to the presence of aggressive agents to the tissues, from the increase of the degree of cellularity and other tissue elements ${ }^{1}$. It is believed that, in relation to peristomal granulomas, the reaction that occurs is triggered by irritation of the skin at the suture sites, or by the retention of the sutures for a prolonged time ${ }^{2-4}$. In addition, peristomal granulomas may arise as a result of skin irritation arising from contact with effluents, such as feces and urine ${ }^{5}$.

It is observed the presence of granulomas in patients with stomies both in the mid and late postoperative periods, which may arise in isolated, multiple points or around the entire stoma ${ }^{3}$. Such tissues are rich in capillaries on their surface, which causes them to bleed easily when handled ${ }^{1}$. Due to their macroscopic characteristics, they allow visual diagnosis by the health professional, however, they may also end up becoming generators of nuisance and anxiety on the part of the patients ${ }^{6}$.

Traditionally, peristomal granulomas have been treated with the use of silver nitrate, which has become the first choice of treatment, because it favors rapid application and is painless to the patient $t^{3-6}$. If treatment with silver nitrate is ineffective, topical corticosteroids and/or liquid nitrogen (cryotherapy) is used. Trichloroacetic acid (TCA), commonly used in specialties such as dermatology, dentistry, gynecology and urology for the treatment of ingrown nails, oral, vaginal and anal condylomatous lesions, chemical peeling, among others, can also be applied in the stomatherapy with the objective of removing granulomas, from chemical cauterization ${ }^{7-12}$. 
Such acid, commonly used in the form of the solution, can also be found in the presentation of paste or jelly ${ }^{13}$.

According to the Brazilian Society of Dermatology, the treatment with TCA consists of the application of acid to certain types of lesions, with the purpose of regression and subsequent removal ${ }^{12}$. Although widely used, there is great difficulty in finding references that address the use of TCA, as well as the peristomal granulomas themselves. Authors explain that the reasons for so few publications may be related to the fact that granulomas do not necessarily cause physical discomfort to patients, usually being painless lesions, resulting in little interest in research involving them, in addition to their therapeutic modalities ${ }^{3}$. In this sense, such a study becomes fundamental, since it will provide information and serve as the scientific basis for knowledge in the treatment of granulomas.

For the treatment of peristomal granulomas, the treatment with $50 \% \mathrm{TCA}$ is proposed, aiming at complete regression of the lesions without damage to the patients. Traditionally, TCA is used in concentrations ranging from 10 to $70 \%$, a percentage that influences its penetration into the lesion; however, it is known that the treatment with concentrations higher than $50 \%$ is related to the greater number of scars and changes in the skin color at the application spot ${ }^{13}$. The process of chemical cauterization of lesions with this acid is usually performed once a week until complete resolution, and it is recommended that it be performed by a qualified professional and through the establishment of an institutional protocol, as established by the Federal Nursing Council of São Paulo to a treatment of condylomatous lesions ${ }^{14,15}$.

Due to its caustic action, which results in cell death by protein denaturation, TCA causes the lesions to become whitish immediately after their application ${ }^{13}$. Local irritation from the use of acid causes some patients to feel burning or pain during the procedure, and there may be cases of adjacent tissue necrosis as well as ulceration ${ }^{9}$. In this sense, it is necessary to emphasize that the peristomal skin and also the mucosa of the stoma must be preserved of the acid, and therefore the application by qualified professional and of cautious form is indispensable. During the application of TCA, the preservation of adjacent tissues is usually done with the use of petroleum jelly or protective materials, such as hydrocolloid compounds. Authors also recommend the availability of neutralizing agents, such as sodium bicarbonate, in cases of overuse ${ }^{9}$.

\section{OBJETIVES}

To describe the clinical results of the treatment of peristomal granulomas in patients with ostomies with the use of $50 \%$ TCA.

\section{METHODS}

It is a case series study by professionals in a reference center for the treatment of individuals with ostomies in the city of Porto Alegre, state of Rio Grande do Sul, conducted in the period from April to June 2017. In 2013, the year in which the investigation of data of the services data was carried out, it had, on average, 791 active records, 396 (50.06\%) male users and 395 (49.9\%) female. The majority of them [512 (64.72\%)] were 60 years of age or older, while $259(32.74 \%)$ were in the age range of $19-59$ years, five $(0.63 \%)$ between $12-18$ years and 17 (2.14\%) between 0-12 years. As for the type of ostomy, colostomies were the most frequent, presenting 463 (58.53\%) users, followed by ileostomies [151 (19.08\%)], urostomies [68 (8.59\%)], nephrostomies [4 (0.5\%)] and fistulas [2 (0.25\%)].

For data collection, the following inclusion criteria were followed: patients enrolled in the study service who were being followed up at a nursing consultation for the treatment of peristomal granulomas. Exclusion criteria were: patients registered in situations of withdrawal or abandonment of the service; individuals without peristomal granulomas; and those who refused to participate in the study. Granulomas, from their peculiar characteristics, were identified and diagnosed visually during consultations with the stomaterapist nurse. Thus, the sample of this study is of 13 patients who fully met the inclusion criteria established.

Data collection was performed during nursing consultations, based on observation and photographic record of granulomas, with subsequent evolution in the individual files. In that sense, the patients were followed up by the stomatologist nurse, checking whether or not there was a regression of the granuloma using the 
TCA. In the cases of patients who were absent from the scheduled appointments, a telephone call was made, in order to alert them about the frequency of consults and the importance of regular treatment. After data collection, the data were organized in a spreadsheet, analyzed and presented by means of descriptive statistics.

It is important to highlight that the $50 \%$ TCA was purchased in a compounding pharmacy and the choice for its use was motivated by its practicality, effectiveness described in the literature and low cost, as well as difficulties in accessing products such as silver nitrate in the market. For its careful application, a swab embedded in the solution was used.

The study was approved by the Research Ethics Committee of the Municipal Health Department of the Municipality of Porto Alegre under opinion $\mathrm{n}^{\circ}$ 2.091.735. In the development of this project, the due ethical aspects were respected, observing strictly the Resolution 466/12 of the National Health Council, which provides on the guidelines and norms regulating research involving human beings16.

It is important to note that the data were only obtained after clarifying to participants the goals of the research and their rights, through the Free and Informed Consent Form, signed by them and by the researchers involved. In addition, to authorize the photographic records and use of images, the patients filled out a specific term.

\section{RESULTS}

Thirteen patients with peristomal granulomas were attended, who accepted to participate in the study. Regarding the characterization of the individuals, there was a predominance of females, with nine women (69.2\%), and the ages of the participants ranged from 4 to 84 years, with a mean age of 59.54 years. Colostomy prevailed among types of stoma present in eight (61.5\%) individuals. With regard to the underlying diseases for the manufacture of the ostomy, neoplasias predominated, presented by nine (69.2\%) individuals, is also identified as diverticular disease, cerebral palsy and hydronephrosis. The only pediatric patient enrolled in the study, at the age of four, had gastrostomy due to cerebral palsy.

The number of TCA applications ranged from one to eight. Eight patients (61.5\%) received regular treatment with TCA weekly until complete regression of granulomatous lesions, while five (38.5\%) started treatment but did not return to the visits to assess the need to complete it. (Table 1)

Table 1. Relationship between the number of participants and number of trichloroacetic acid (TCA) applications for granuloma resolution.

\begin{tabular}{ccc}
\multirow{2}{*}{ TCA applications $(\mathrm{n})$} & \multicolumn{2}{c}{ Participants } \\
\cline { 2 - 3 } & $(\mathrm{n})$ & $(\%)$ \\
\hline 2 & 3 & 37,5 \\
\hline 2 & 1 & 12,5 \\
\hline 5 & 3 & 37,5 \\
\hline 8 & 1 & 12,5 \\
\hline
\end{tabular}

Among the five individuals who did not return to the service for reassessment, three (60\%) applied the TCA only once, while the other two (40\%) applied three times without record of resolution of the lesion. No complications were recorded from the use of TCA in the present study.

Figure 1 presents some of the photographic records made during the consults of the patients treated, aiming to compare them weekly to evaluate the effectiveness of the TCA in the regression and resolution of peristomal granulomas.

Figure 1. Photographic images made to evaluate the regression of peristomal granulomas during treatment with trichloroacetic acid (TCA).

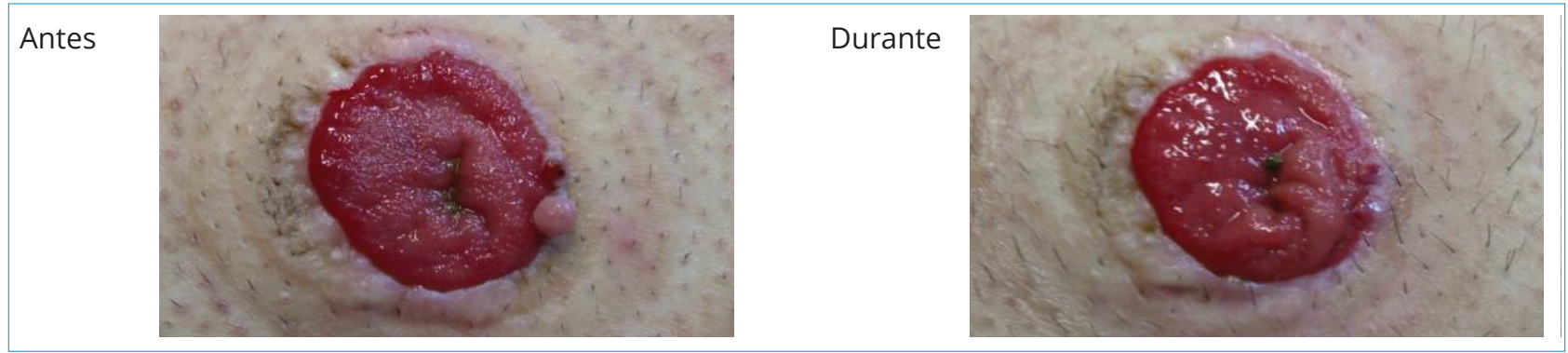


Figure 1. Continuation...

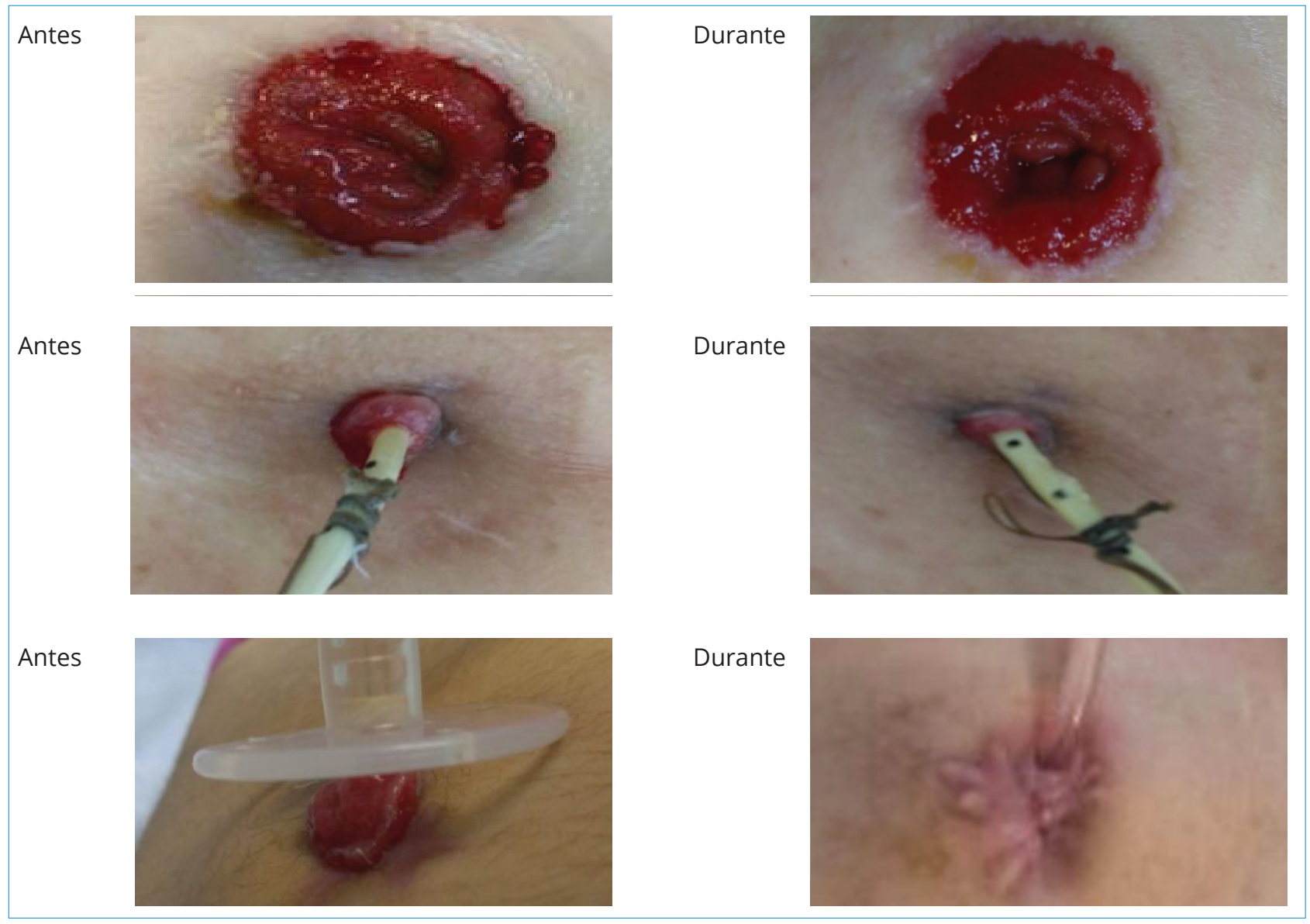

Source: author's personal files.

\section{DISCUSSION}

Research conducted in the state of Minas Gerais in 2010 pointed out the predominance of females $(66.7 \%)$ among individuals with ostomies ${ }^{17}$, the same occurred in Teresina, state of Piauí, where a study found $62.50 \%$ of women in their sample ${ }^{18}$, data that meet the identified among the individuals of the present study. Regarding the age group, a study indicates the average age of 61.6 years among the population with studied stomies ${ }^{17}$, little more than the 59 years found. According to Boccardo et al. ${ }^{19}$, there is a predominance of individuals with ostomies in the age group between 58 and 78 years and, according to Macedo et al. ${ }^{18}$, this can be explained by the fact that the age over 40 years is a risk factor for the appearance of diseases such as cancer, which sometimes has, as part of the treatment, the confection of an ostomy.

With regard to the characterization of the ostomy, a study identified a predominance of patients with colostomy (81.25\%), followed by urostomies (12.50\%) and ileostomies (6.25\%), ${ }^{18}$. It is known that the performance of the ostomy is directly related to the treatment of comorbidity that can affect different organs and body systems $s^{20}$. In this sense, these results differed in part from those identified in the present study, in which urinary system pathologies were inferior to intestinal diseases in general. However, it is consistent that most of the ostomies are located in the colon, that is, in the large intestine.

Also in other studies, neoplasia was considered the most prevalent base disease for the manufacture of the ostomy, followed by inflammatory diseases ${ }^{17,18}$. Cancer is considered an important public health problem since, each year, millions of new cases are diagnosed worldwide $^{21}$. In Brazil, the estimated number in 2014 and 2015 was approximately 576 thousand cases ${ }^{22}$. It is known that, as in other diseases, the development of cancers results from a complex interaction between 
genetic and environmental factors. Regarding colon and rectum neoplasms, for which colostomy can be indicated as part of the treatment, about one million new cases worldwide are diagnosed each year ${ }^{21}$.

During the last two decades, the number of cases of cerebral palsy in childhood has increased, which may be related to the improvement in perinatal care, which increases the survival of premature and low-weight children. In addition to causing neuromotor impairments, cerebral palsy may result in impairment of performance of daily activities, such as feeding by self ${ }^{23}$. In this sense, gastrostomy has as one of the most common indications the problems of neurological cause and is used as a means of substitution to the nasoenteric catheter in patients who need to receive nutritional support for a prolonged time ${ }^{24}$, as the participant of this study.

Regarding the treatment of peristomal granulomas with TCA, it was observed in the present study that the need for applications was related to the size and quantity of granulomas around the stoma. In this sense, individuals presenting larger or larger granulomas required a greater number of applications for resolution, while smaller granulomas were more easily resolved from a smaller number of TCA applications. In addition, in cases where the aggressive agents re-contacted the tissues after the procedure, such as in situations of effluent leakage and tube/catheter friction with the peristomal skin, more acid applications were required for resolution of the lesion. Since granulomas do not usually cause great discomfort and pain to individuals, it is suspected that the low adherence to regular treatment in this study is related to this fact.

The treatment of lesions with the use of TCA is a favorable therapeutic option, which is not traumatic to the patients and is affordable but needs to be further studied, considering that currently there are few references, especially in the stomatherapy area. Studies using TCA for the treatment of condylomatous lesions indicate that such an acid is more effective for the treatment of small lesions and that it has a response rate of up to $80 \%$, thus obtaining good healing results. Another positive point highlighted by authors is the fact that TCA is not systemically absorbed ${ }^{9}$.

Thus, patients who underwent treatment for peristomal granulomas regularly with the use of TCA obtained regression of the lesions until their total disappearance. However, it has to be considered that the use of the TCA presents some risks, as it happens with other materials composed by acids, and can cause accidental burns, which can be minimized with the use of the technique and materials appropriate to the procedure, as well as human resources.

\section{CONCLUSION}

From this study, it was observed that the regular treatment with TCA had a positive effect on the regression of the granulomas until their total disappearance. Such an outcome may favor the care of patients with a stoma, since the TCA is an effective treatment alternative, with an accessible value and easy to apply. Therefore, it is recommended to carry out more studies on the use of TCA in stomatherapy, seeking the use of more robust clinical research methodologies and with bias control.

\section{AUTHOR'S CONTRIBUTION}

Conceptualization, Paczek RS and Passberg LZ; Methodology, Paczek RS and Passberg LZ; Investigation, Paczek RS and Passberg LZ; Writing - First version, Paczek RS and Passberg LZ; Writing - Reviewing \& Editing, Paczek RS and Passberg LZ; Resources, Paczek RS; Supervision, Paczek RS.

\section{REFERENCES}

1. Corrêa L. Inflamação crônica e granulomas. São Paulo: Universidade de São Paulo; 2000.

2. Zulkowski K. Ostomy terms and definitions. WCET. 2015;35(3):48-50.

3. Yamada BFA, Peres CSV, Santos VLCG. Granuloma em gastrostomia: uma alternativa inovadora de tratamento tópico. ESTIMA, Braz J Enterostomal Ther. 2004;2(4):11-4.
4. Steinhagen E, Colwell J, Cannon LM. Intestinal stomas postoperative stoma care and peristomal skin complications. Clin Colon Rectal Surg. 2017;30(3):184-92. https://doi. org/10.1055/s-0037-1598159

5. Monteagudo B. Hipergranulación periestomal. Med Cutan Iber Lat Am. 2009;37(1):64-6. 
6. Dukes S, Lowther C, Martin T, Osborne D. Guidelines for treating stoma granulomas at the mucocutaneous junction. Gastroenterol Nurs. 2010:8(1):16-21. https://doi. org/10.12968/gasn.2010.8.1.46674

7. Ricardo HJ, Lorduy MC, Caballero AD. Efectividad de la terapia con ácido tricloroacético en el tratamiento de lesiones en la hiperplasia epitelial focal. Rev Odont Mex. 2016;20(4): 23076. https://doi.org/10.1016/j.rodmex.2016.11.004

8. Barreiros H, Matos D, Goulão J, Serrano P, João A, Brandão FM. Using $80 \%$ trichloroacetic acid in the treatment of ingrown toenails. An Bras Dermatol. 2013;88(6):889-93. https://doi.org/10.1590/abd1806-4841.20132296.

9. Brás F, Sardinha R, Pacheco A. Modalidades terapêuticas no tratamento dos condilomas acuminados. Acta Obstet Ginecol Port. 2015;9(5):383-92.

10. Nadal SR, Manzione CR. Manejo dos portadores das neoplasias intraepiteliais anais. Rev bras colo-proctol. 2008;28(4):462-4. https://doi.org/10.1590/S0101-98802008000400009

11. Neto JCP, Silva TAA, Lago AFV, Rodrigues ABL, Nogueira NMCC, Bandeira WF, et al. Utilização do peeling químico nas alterações estéticas: uma revisão de literatura [Internet]. Teresina: Anais-Revista Interdisciplinar de Ciências Médicas; 2017. [cited 21 jan 2019]. Available at: https://gpicursos. com/interagin/gestor/uploads/trabalhos-feirahospitalarpia ui/4ab07057eb64e608cd0f2de5e12ba09c.pdf

12. Sociedade Brasileira de Dermatologia. Cauterização química [Internet]. Rio de Janeiro: SBD; 2016 [cited 19 jan 2019]. Available at: www.sbd.org.br/dermatologia/pele/ procedimentos/cauterizacao-quimica/2/

13. Zanini M. Gel de ácido tricloroacético - Uma nova técnica para um antigo ácido. Med Cutan Iber Lat Am. 2007;35(1):14-7.

14. Castro TMPPG, Duarte ML. Condiloma lingual: relato de caso clínico. Rev Bras Otorrinolaringol. 2004;70(4):565-8. https:// doi.org//10.1590/50034-72992004000400021

15. Conselho Regional de Enfermagem de São Paulo. Parecer Coren-SP 001/2015 de 07 de outubro de 2014 [Internet]. Brasília: 2015 [cited 21 jan 2019]. Available at: https://portal. coren-sp.gov.br/wp-content/uploads/2015/04/Parecer\%20 001-2015.pdf
16. Ministério da Saúde (BR). Resolução n 466 de 12 de dezembro de 2012 [Internet]. Brasília, DF: 2012 [cited 18 apr 2017]. Available at: https://conselho.saude.gov.br/ resolucoes/2012/Res0466.pdf

17. Fernandes RM, Miguir ELB, Donoso TV. Perfil da clientela estomizada residente no município de Ponte Nova, Minas Gerais. Rev bras colo-proctol. 2010;30(4):385-92. https:// doi.org/10.1590/S0101-98802010000400001

18. Macedo MS, Nogueira LT, Luz MHBA. Perfil dos estomizados atendidos em hospital de referência em Teresina. ESTIMA, Braz J Enterostomal Ther. 2005;4(4)25-8.

19. Boccardo LM, Nogueira AS, dos Santos ER, Miyadahira AMK, Santos VLCG. Aspectos da reinserção social do ostomizado. Rev esc enferm USP. 1995;29(1):59-71. https:// doi.org/10.1590/0080-6234199502900100059

20. Crema E, Silva R. Estomas: uma abordagem interdisciplinar. Uberaba: Pinti; 1997.

21. Santos Junior JCM. Câncer ano-reto-cólico: aspectos atuais II - Câncer colorretal - Fatores de riscos e prevenção. Rev bras colo-proctol. 2007;27(4):459-73. https://doi.org/10.1590/ $\underline{\mathrm{S} 0101-98802007000400016}$

22. Instituto Nacional de Câncer. Estimativa 2018. Incidência de câncer no Brasil [Internet]. Rio de Janeiro: INCA; 2018 [cited 21 Jan 2019]. Available at: https://www.inca.gov.br/ publicacoes/livros/estimativa-2018-incidencia-de-cancerno-brasil

23. Mancini MC, Fiúza PM, Rebelo JM, Magalhães LC, Coelho ZAC, Paixão ML, et al. Comparação do desempenho de atividades funcionais em crianças com desenvolvimento normal e crianças com paralisia cerebral. Arq NeuroPsiquiatr. 2002;60(2-B):446-52. https://doi.org/10.1590/ S0004-282X2002000300020

24. Vilarinho RSC, Rogenski NMB, Rogenski KE. Gastrostomia: como cuidar. In: Cesaretti IUR, Paula MAB, Paula PR. Estomaterapia: temas básicos em estomas. São Paulo: Cabral; 2006. p. 243-50. 